\title{
Cardanols detected in non-polar propolis extracts from Scaptotrigona aff. postica (Hymenoptera, Apidae, Meliponini)
}

\section{Cardanols detectados nos extratos apolares da própolis de Scaptotrigona aff. postica (Hymenoptera, Apidae, Meliponini)}

\section{Giuseppina Negri* (D), Caroline Cristina Fernandes Silva1, Guilherme Rabelo Coelho², Roberto Manoel do Nascimento², Ronaldo Zucatelli Mendonça²}

${ }^{1}$ Universidade de São Paulo (USP), Instituto de Biociências, Departamento de Botânica, Laboratório de

Fitoquímica, São Paulo/SP - Brasil

${ }^{2}$ Instituto Butantan, Laboratório de Parasitologia, São Paulo/SP - Brasil

*Corresponding Author: Giuseppina Negri, Universidade Federal de São Paulo (UNIFESP), Centro Brasileiro de Informações sobre Drogas Psicotrópicas, Departamento de Medicina Preventiva, Rua Botucatu, 740, Vila

Clementino, CEP: 04023-062, São Paulo/SP - Brasil, e-mail: gnegri@terra.com.br

Cite as: Negri, G., Silva, C. C. F., Coelho, G. R., Nascimento, R. M., \& Mendonça, R. Z. (2019). Cardanols detected in non-polar propolis extracts from Scaptotrigona aff. postica (Hymenoptera, Apidae, Meliponini). Brazilian Journal of Food Technology, 22, e2018265. https://doi.org/10.1590/1981-6723.26518

\begin{abstract}
The propolis produced by stingless bees of the tribe Meliponini is a viscous product that contains the resin collected from buds, leaves and plant exudates, mixed with salivary secretions, wax and soil. The species Scaptotrigona aff. postica (Latreille, 1807), (Hymenoptera, Apidae, Meliponinae) popularly known as "tubi" in Maranhão State, Brazil, does not mix soil to produce its propolis. The propolis from S. postica harvested in Barra do Corda, Maranhão State, is popularly used in the treatment of wounds and respiratory illnesses. The hydroalcoholic extract of this propolis, rich in flavone-6,8-di-C-glycosides (vicenin-2 and schaftoside), pyrrolizidine alkaloids derived from retronecine, catechin and caffeoylquinic acid derivatives exhibited antiviral activity against the herpes simplex and rubella viruses. The aim of this study was to increase knowledge about the chemical composition of the S. postica propolis by analyzing non-polar extracts obtained using hexane and chloroform as the solvents, by GC-El-MS. A total of 15 constituents were identified comparing their respective mass spectral data with those available in the NIST data bases and those reported in the literature. The main constituents detected were the phenolic lipids, known as cardanols, 3-(4,7-heptadecadienyl) phenol (5), 3-(10-heptadecenyl) phenol (7), 3-heptadecylphenol (9) and 3-pentadecyl phenol or hydrocardanol (13), which predominated in the hexane extract, while the predominant constituents in the chloroform extract were 3-pentadecyl phenol or hydrocardanol (13) and 3-(8-pentadecenyl) phenol (12). The antioxidant, antitumoral, antifeedant, cytotoxic, anticarcinogenic, antiproliferative, antimicrobial, antileishmanial and lanvicidal activities of the cardanols have been demonstrated in many studies.
\end{abstract}

Keywords: Chemical analyses; Stingless bee propolis; GC-El-MS; 3-pentadecylphenol; 3-(10-heptadecenyl) phenol; Pharmacological activity.

\section{Resumo}

A própolis elaborada pelas abelhas sem ferrão (Apidae, Meliponini) é um material resinoso extraído de brotos, folhas e 
exsudatos de plantas, que são misturados com secreções salivares, cera e solo. A espécie Scaptotrigona aff. postica (Latreille, 1807), (Hymenoptera, Apidae, Meliponini), popularmente conhecida como "tubi", no estado do Maranhão, não mistura solo na produção da própolis. A própolis de S. postica coletada no município de Barra do Corda, estado do Maranhão, é usada popularmente no tratamento de feridas e doenças respiratórias. O extrato hidroalcoólico desta própolis é rico em flavonas-6,8- C -glicosídeos (vicenina e schaftosídeo), alcaloides pirrolizidínicos, catequinas e ácidos cafeoilquínicos, e mostrou atividade antiviral contra os vírus do herpes e da rubéola. O objetivo deste estudo foi ampliar o conhecimento sobre a composição química da própolis de S. postica, analisando os extratos apolares obtidos usando hexano e clorofórmio como solventes, por cromatografia gasosa acoplada a espectrometria de massas. Os 15 constituintes detectados foram identificados comparando os seus respectivos espectros de massas com espectros de massas compilados nas bases de dados NIST e reportados na literatura. Os principais constituintes encontrados foram os lipídios fenólicos, conhecidos como cardanóis, 3-(4,7-heptadecadienil) fenol (5), 3-(10-heptadecenil) fenol (7), 3-heptadecilfenol (9) e 3-pentadecilfenol ou hidrocarbônico (13), que predominaram no extrato hexânico, enquanto que, no extrato clorofórmico, os constituintes predominantes foram 3-pentadecilfenol ou hidrocarbônico (13) e 3-(8-pentadecenil) fenol (12). As atividades antioxidante, antitumoral, citotóxica, antiproliferativa e larvicida dos cardanóis foram demonstradas através de vários estudos.

Palavras-chave: Análise química; Própolis de abelhas sem ferrão; CG-EM; 3-pentadecilfenol; 3-(10-heptadecenil) fenol; Atividade farmacológica.

\section{Introduction}

Propolis is produced by the Africanized bee Apis mellifera (Huang et al., 2014) and by stingless bees of the tribe Meliponini (Batista et al., 2016) from resinous material collected from the buds, flowers and exudates of different plants, which is mixed with their mandibular secretions and wax. Some species of stingless bees add soil in the elaboration of their geopropolis (Dutra et al., 2014; Liberio et al., 2011), but the stingless bees Scaptotrigona aff. postica (Latreille, 1807), (Hymenoptera, Apidae, Meliponini), popularly known as "tubi", in Maranhão State, Brazil, produce their propolis without the addition of soil (Souza et al., 2015; Sawaya et al., 2009). Stingless bees or meliponines play an important role in pollination and agriculture and are present in tropical and neotropical regions throughout the world (Batista et al., 2016; Pedro, 2014). Although the meliponines comprising the tribe Meliponini, possess stingers, they cannot be used in their defense. Stingless bees are less harmful to humans and domestic animals and are more resistant to the diseases and parasites than Apis mellifera (Sawaya et al., 2009; Araújo et al., 2015). In Brazil, 244 stingless bee species have been identified, mainly in the northern and northeastern regions, corresponding to about $20 \%$ of all neotropical species of stingless bees (Pedro, 2014).

The chemical composition of propolis varies according to the flora visited by the bees, the region, and the time of collection (Huang et al., 2014; Pasupuleti et al., 2017). Consequently, their quality and biological activities vary according to their botanical origin (Araújo et al., 2015; Ribeiro-Junior et al., 2015). The chemical composition of propolis from Apis mellifera is qualitatively the same in the geographic region where it was produced. For example, the Brazilian green propolis harvested in the southeast region of Brazil, is elaborated using Baccharis dracunculifolia as the resin source and possesses prenylated phenylpropanoids, caffeoylquinic acids and diterpenes as the main constituents (Oliveira et al., 2014; Righi et al., 2013; Fernandes-Silva et al., 2013).

On the other hand, in general, propolis from stingless bees exhibits a wide variation even among samples from the same region, since they collect material from plants near their hives (Araújo et al., 2015; Ribeiro-Junior et al., 2015). Thus, for example, cycloartane, ursane and oleanane derivatives and phenolic acids (protocatechuic acid and gallic acid) were detected in the geopropolis from Melipona fasciculata harvested in Palmeirândia, while gallic and ellagic acids were the main constituents detected in the geopropolis harvested in Fernando Falcão, both municipalities located in Maranhão State, northeastern Brazil (Batista et al., 2016). In addition, hydrolyzable tannins (gallotannins and ellagitannins) and phenolic 
acids were detected in the geopropolis from Melipona fasciculata Smith harvested in Baixada Maranhense, Brazil (Dutra et al., 2014). However, the geopropolis samples from Tetragonisca angustula, independent of their geographic origin, presented a chemical composition similar to extracts from the flowers of Schinus terebinthifolius Raddi (Anacardiaceae), which was probably their resin source (Carneiro et al., 2016). Therefore, knowledge of the composition of propolis and of the plants visited as resin sources is very important (Sawaya et al., 2007).

Phenylpropanoids (Souza et al., 2013), di- and trigalloyl and phenylpropanyl heteroside derivatives (Santos et al., 2017a), hydrolysable tannins (Dutra et al., 2014), terpenes (monoterpenes, sesquiterpenes, diterpenes and triterpenes) (Torres et al., 2018; Santos et al., 2017a), fatty acids (Bankova et al., 1998), saponins (Araújo et al., 2015; Dutra et al., 2008), anacardic acid derivatives (Silva et al., 2008; Araújo et al., 2015) and alkaloids (Coelho et al., 2015) have been detected in the propolis from stingless bees. Flavonoids were detected in the geopropolis from the stingless Amazonian bees Melipona interrupta (Silva et al., 2013). Flavonoids, derivatives of glycosylated phenolic acids and terpenoids were detected in the geopropolis from the stingless bee Melipona orbignyi (Santos et al., 2017b). Prenylated benzophenone and cinnamic acid esters were detected in the geopropolis from Melipona scutellaris Latreille, indicating that a genus of the Clusiaceae family, especially Kielmeyera and Clusia, could be the resin sources of this geopropolis (Cunha et al., 2016). The phenylpropanoids, 6-O-p-coumaroyl-D-galactopyranose and 6-O-cinnamoyl-1-O-p-coumaroyl$\beta$-D-glucopyranose, and flavonoids were detected in the geopropolis from Melipona subnitida Ducke (jandaíra), a stingless bee native to northeastern Brazil (Souza et al., 2013, 2018).

The isolation of the cycloartane triterpene magniferolic acid and 3 $\beta$-hydroxy-24-methylenecicloartan-26-oic acid, besides the flavonoids 3'-methyl quercetin, sakuranetin and kaempferol 7-methyl ether, indicated the exudates from Eucalyptus citriodora specimens as the resin source for the production of geopropolis from Trigona spinipes Fabricius, native to the Northeast of Brazil (Freitas et al., 2008). Di- and trigalloyl and phenylpropanyl heteroside derivatives, flavanones, diterpenes and triterpenes were detected in the geopropolis from Melipona quadrifasciata anthidioides, which exhibited activity in the prevention and treatment of various diseases related to oxidative stress, mutagenesis, inflammatory processes and microbial infections (Santos et al., 2017a). Triterpenoids are the chemical markers for the standardization of geopropolis from the Malaysian stingless bees, Heterotrigona itama (Zhao et al., 2017).

Qualitative and quantitative differences in the chemical composition of propolis can influence its biological activity (Santos et al., 2017b; Franchin et al., 2012). However, the propolis produced by different species of stingless bees in different regions of the world, exhibit antimicrobial (Cunha et al., 2013a), anticancer, antioxidant (Ferreira et al., 2017), anti-inflammatory (Araújo et al., 2015; Santos et al., 2017a, 2017b, 2017c), gastroprotective (Ribeiro-Junior et al., 2015), and antiviral (Coelho et al., 2015) activities. The geopropolis produced by Melipona fasciculata Smith exhibited antimicrobial activity against Streptococcus mutans and Candida albicans (Liberio et al., 2011). The geopropolis from Melipona scutellaris Latreille exhibited antimicrobial, antioxidant, anti-inflammatory, antinociceptive (Franchin et al., 2012; Silva et al., 2014) and antiproliferative activities (Cunha et al., 2013b, 2016). The geopropolis from Melipona orbignyi exhibited antioxidant, anti-inflammatory, antimutagenic and antimicrobial activities (Santos et al., 2017b), while the geopropolis from Melipona mondury exhibited therapeutic potential against inflammatory and oxidative infectious and neoplastic diseases (Santos et al., 2017c).

Large amounts of flavone-6,8-di- $C$-glycosides (vicenin-2 and schaftoside), pyrrolizidine alkaloids derived from retronecine, catechin derivatives and caffeoylquinic acid derivatives (Coelho et al., 2015), and lesser amounts of the hydroxycinnamic acid amide derivatives (Coelho et al., 2018) were detected in the hydroalcoholic extract of propolis from Scaptotrigona aff. Postica, harvested in Barra do Corda, Maranhão State. This extract exhibited antiviral activity against the herpes simplex (Coelho et al., 2015; Silva-Carvalho et al., 2015) and rubella (Coelho et al., 2018) viruses. Since the propolis from S. postica is a potential source of new bioactive compounds, more studies, including the chemical composition and biological activity of non-polar extracts, are needed to add 
value to this bee product. Thus, the objective of this study was to carry out chemical analyses of the non-polar hexane and chloroform extracts obtained from the propolis of S. postica, using GC-EI-MS.

\section{Material and methods}

\subsection{Non-polar extracts}

The samples of propolis from S. postica were collected from beehives located in the municipality of Barra do Corda, in the central region of Maranhão State, northeastern Brazil ( $\left.5^{\circ} 30^{\prime} \mathrm{S}, 45^{\circ} 14^{\prime} \mathrm{O}\right)$, in November 2011. The ecosystems of this region include mangrove swamps, floodplains, lakes and babassu palm forests. The apiary is located $100 \mathrm{~m}$ from the right side of the Mearim River.

The extractions were carried out in a Soxhlet apparatus using $5 \mathrm{~g}$ of propolis and $30 \mathrm{~mL}$ of either hexane or chloroform separately as the solvent, extracting for 6 hours (Luque de Castro \& García-Ayuso, 1998; Fernandes-Silva et al., 2013). After extraction, the extracts were maintained in a refrigerator for two days and the precipitated wax then filtered off. The presence of soil was not observed. The filtrate was then concentrated in a rotary evaporator under reduced pressure, and finally concentrated to dryness on a water bath at a temperature of $50{ }^{\circ} \mathrm{C}$ to obtain dry hexane and chloroform extracts, which were weighed and analyzed by GC-EI-MS.

\subsection{Analyses of the hexane and chloroform extracts by GC-EI-MS}

$1 \mu \mathrm{L}$ aliquots of $1 \mathrm{mg} \mathrm{mL}^{-1}$ hexane or chloroform solutions of the extracts were injected into the equipment in the split mode, using a Shimadzu GCMS-QP505A gas chromatograph equipped with a ZB-5ms fused silica capillary column BPX5 (non-polar, 5\% phenyl arylene - 95\% dimethylpolysiloxane) (30 $\mathrm{m} \times 0.25 \mathrm{~mm}$ internal diameter $\times 0.25 \mu \mathrm{m}$ film thickness) coupled to an ion-trap mass detector. Mass spectra were acquired in the electron-impact (EI) mode with an ionization voltage of $70 \mathrm{eV}$. The GC conditions were set as follows: the oven was programmed with an initial temperature of $100^{\circ} \mathrm{C}$, which was maintained for $5 \mathrm{~min}$ and then increased to $320^{\circ} \mathrm{C}$ at a rate of $6^{\circ} \mathrm{C} / \mathrm{min}$. The final temperature was maintained for $10 \mathrm{~min}$. The air and hydrogen flow rates were $400 \mathrm{~mL} / \mathrm{min}$ and $29.5 \mathrm{~mL} / \mathrm{min}$, respectively. Helium was used as the carrier gas at a flow rate of $2.1 \mathrm{~mL} / \mathrm{min}$, linear velocity of $53.8 \mathrm{~cm} / \mathrm{sec}$, column pressure of $150.0 \mathrm{KPa}$ and total flow of $29.5 \mathrm{~mL} / \mathrm{min}$. The MS conditions were set as follows: filament current, $0.3 \mathrm{~mA}$; detector voltage, $-0.7 \mathrm{kV}$, ion source temperature, $300{ }^{\circ} \mathrm{C}$; interface temperature, $300{ }^{\circ} \mathrm{C}$; split ratio of 11 and scan speed of 2 scans s $\mathrm{s}^{-1}$. The mass range was 120-700 Da over $52 \mathrm{~min}$ (full scan mode). Identification of the non-polar constituents was carried out by comparison of the mass spectral data with those available in the NIST 08 (National Institute Standards Technology), Wiley-275 (Hewlett Packard) and Wiley/NBS libraries, and data available in the literature. The relative amounts of constituents were assumed to be proportional to the areas under the corresponding chromatogram peaks.

\section{Results and discussion}

This work evaluated the chemical compositions of hexane and chloroform extracts obtained from the propolis of S. postica. The yield of the hexane extract was $15.0 \%$, based on the initial weight of the propolis $(5 \mathrm{~g})$, while the yield of the chloroform extract was $28.0 \%$. Table 1 shows the identification of the constituents by comparason of their mass spectral data with those available in the NIST 08 (NIST Match Factor of 850), Wiley-275 (Hewlett Packard) and Wiley/NBS libraries and in the literature. The identification of the hydrocarbons, 1-pentadecene (1) and 1-heptadecene (3) was based on the NIST MS spectral database and data reported by Siddiquee et al. (2015) and by McNeil et al. (2018). The compound 2,4-di-tert-butylphenol (2) exhibited molecular ions $\mathbf{M}^{+\cdot)}$ at $m / z 206$ and a base peak at $m / z$ 191, indicating the loss of a methyl group, and was identified based on data reported by Kusch et al. (2011) and by 
Irawan et al. (2018). The fatty acids $n$-hexadecanoic acid (4) and $n$-octadecanoic acid (8) were identified based on NIST MS spectral database and data reported by Bankova et al. (1998) and by Hernández-García et al. (2019). The diterpene, (-)-Kaur-16-ene (6) exhibited molecular ions $\mathrm{M}^{+\cdot)}$ at $\mathrm{m} / \mathrm{z} 272$ and a base peak at $\mathrm{m} / \mathrm{z} 257$, and was identified based on NIST MS spectral database and data reported by Xie et al. (2011).

Cardanols or 3-alkylphenols with saturated and unsaturated chains, were the main constituents detected in the hexane and chloroform extracts, as can be seen in Table 1. The cardanols: 3-(4,7-heptadecadienyl) phenol (5) (17\%), 3-(10-heptadecenyl) phenol (7) (21\%) (mass spectrum shown in Figure 1), 3-heptadecyl phenol (9) (31\%) (mass spectrum shown in Figure 2), and 3-pentadecylphenol or hydrocardanol (13) (11\%) predominated in the hexane extracts. The predominant cardanols detected in the chloroform extract were 3-(8-pentadecenyl) phenol (12) (10\%) (mass spectrum shown in Figure 3) and 3-pentadecylphenol or hydrocardanol (13) (48\%) (mass spectrum shown in Figure 4). 5-Alkylresorcinols or cardols were detected in small amounts.

The cardanols exhibited characteristic electron impact mass spectra, with a base peak fragment at $\mathrm{m} / \mathrm{z}$ 108 and a minor fragment at $m / z$ 107, as shown in Table 1 and Figures 1-4, which were produced by simple benzylic cleavage (Wheeler et al., 1997; Ross et al., 2004; Gómez-Caravaca et al., 2010). Very little additional fragmentation was observed. The cardols exhibited a base peak fragment at $m / z 124$, due to the McLafferty rearrangement of the phenolic ring, and another minor fragment at $m / z 123$ (Table 1, Figure 5), due to the dihydroxytropylium ion formed by simple benzylic cleavage (Ross et al., 2004; Saitta et al., 2009; Geerkens et al., 2015).

Table 1. Constituents detected by GC-EI-MS in the non-polar extracts from the geopropolis of Scaptotrigona aff. postica (hymenoptera, apidae, meliponini).

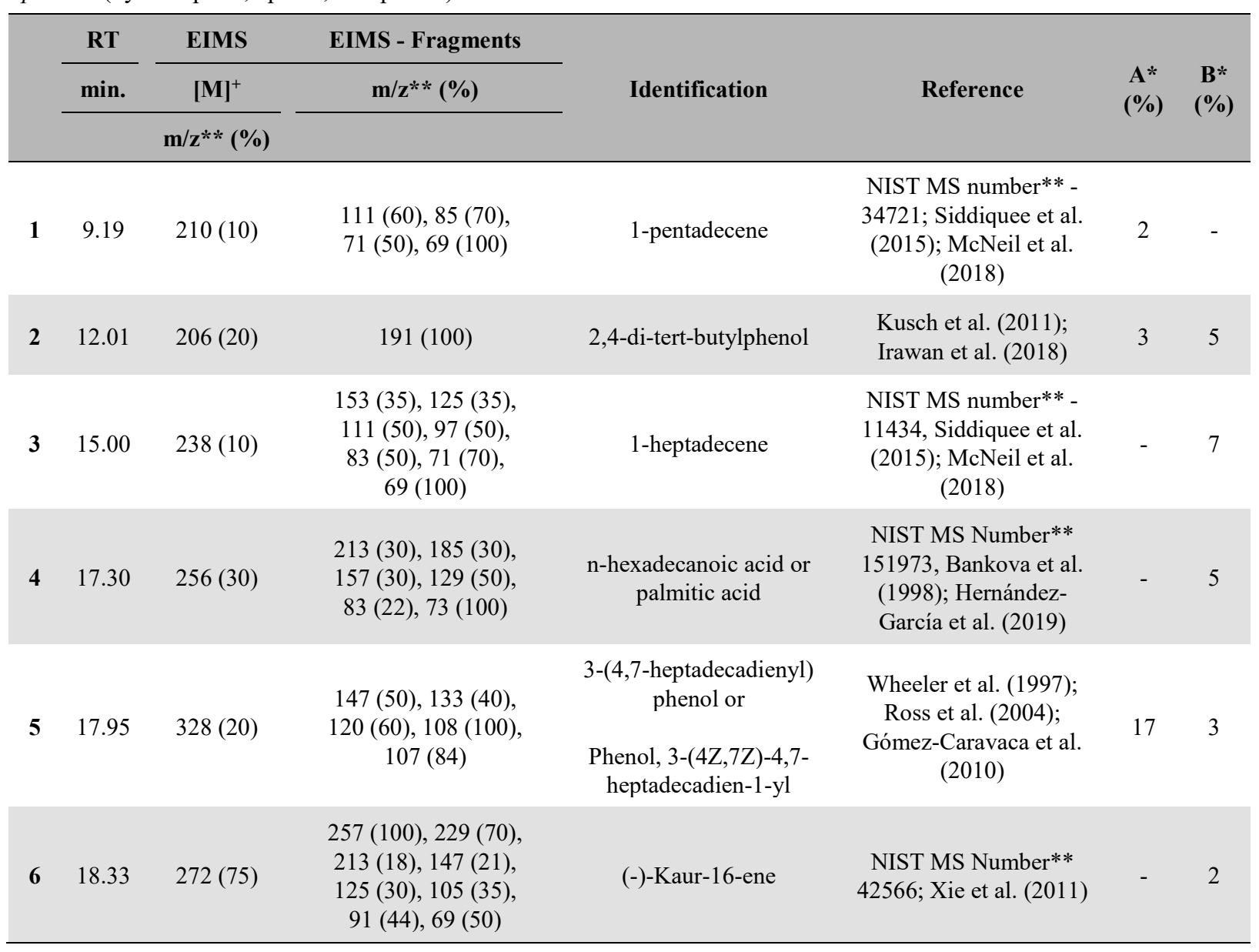


Table 1. Continued...

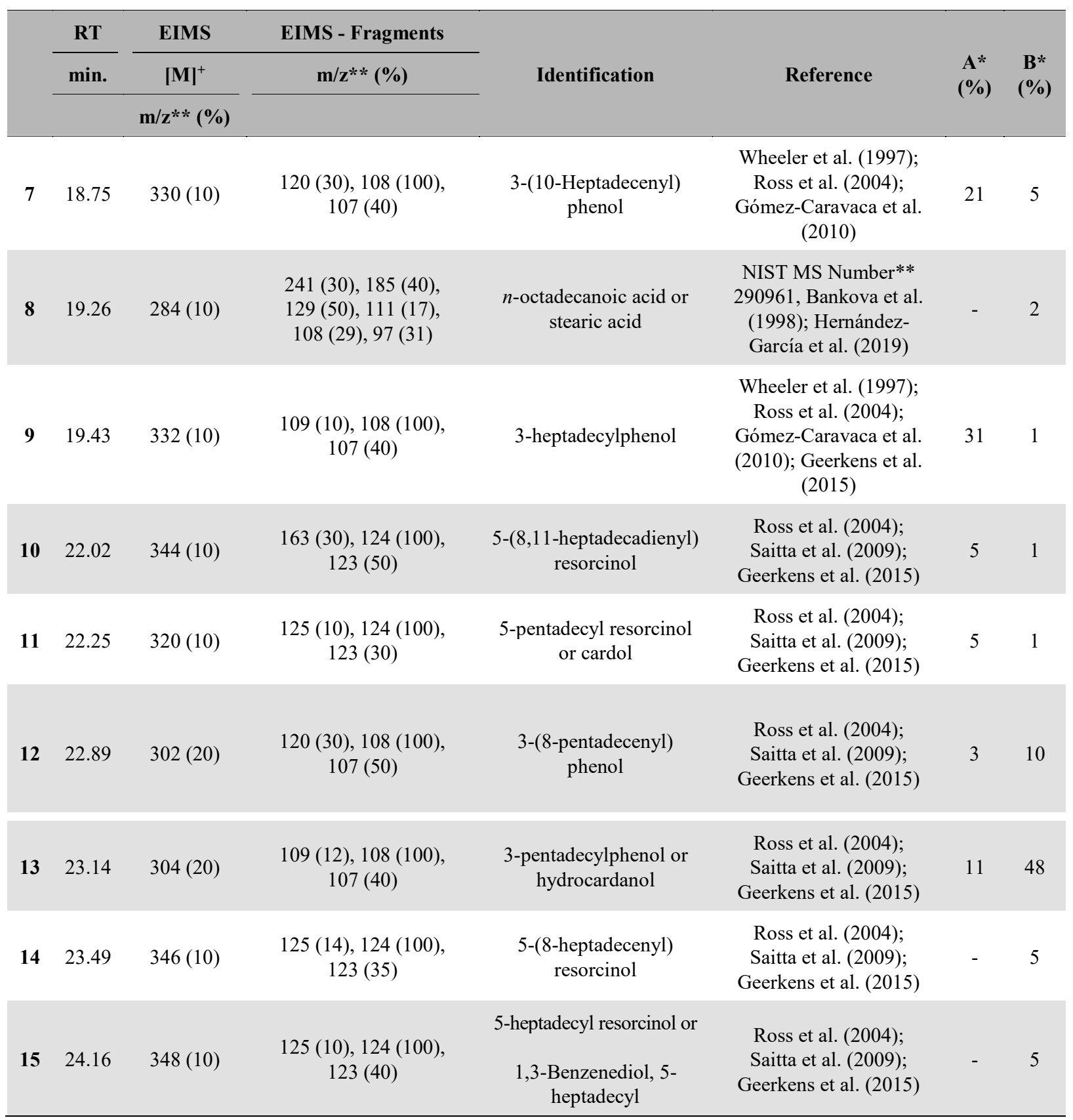

Contents in percentage $(\%) \mathrm{A}=$ hexane extract; and $\mathrm{B}=$ chloroform extract. ${ }^{*}$ mass-to-charge ratio - $\mathrm{m} / \mathrm{z} .{ }^{* * N I S T}$ Match Factor $-850 . \mathrm{RT}=$ retention time; EIMS = electron impact mass spectra. 


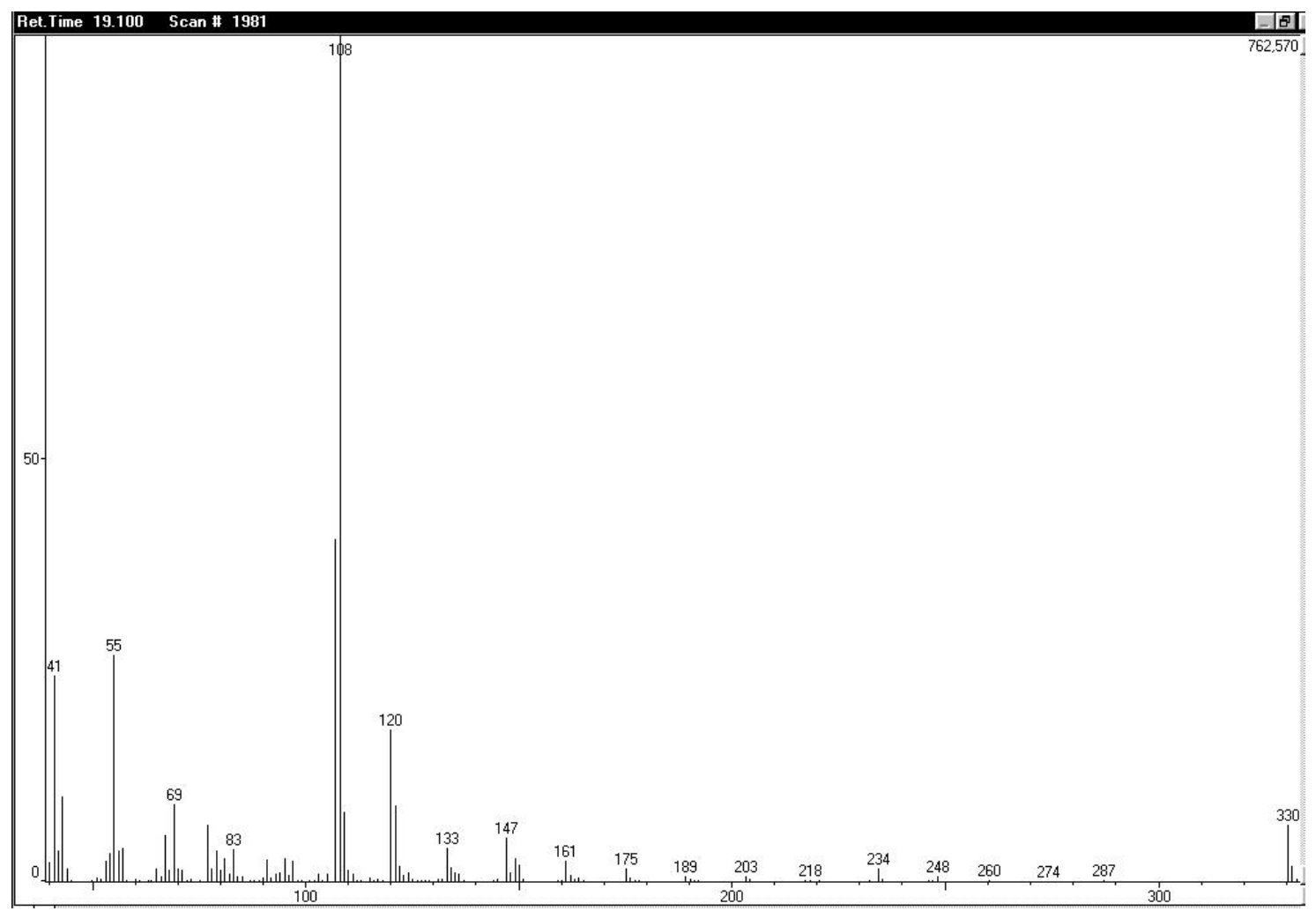

Figure 1. GC-EI-MS of the mass spectrum of 3-(10-heptadecenyl) phenol (7).

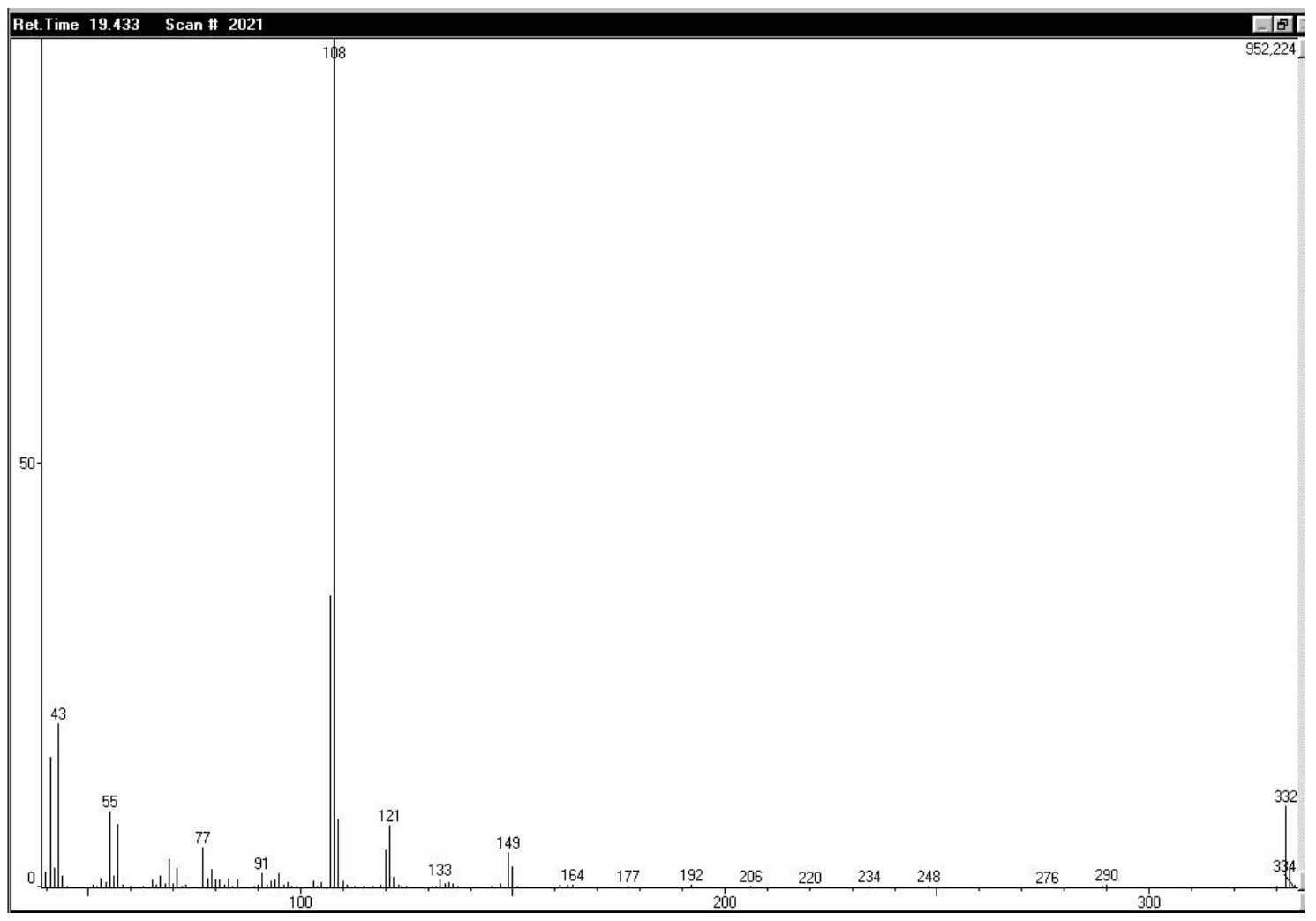

Figure 2. GC-EI-MS of the mass spectrum of 3-heptadecyl phenol (9). 


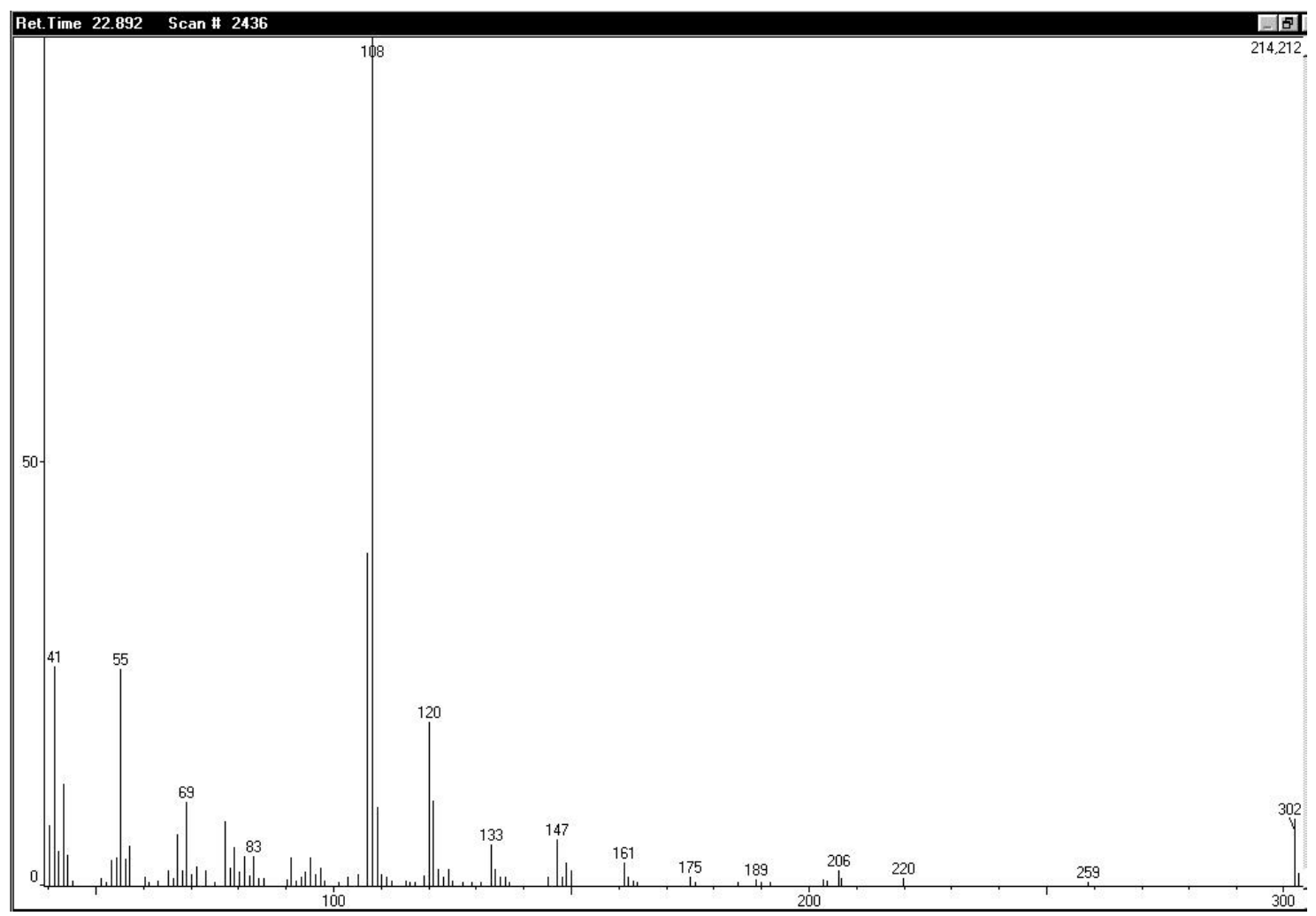

Figure 3. GC-EI-MS of the mass spectrum of 3-(8-pentadecenyl) phenol (12).

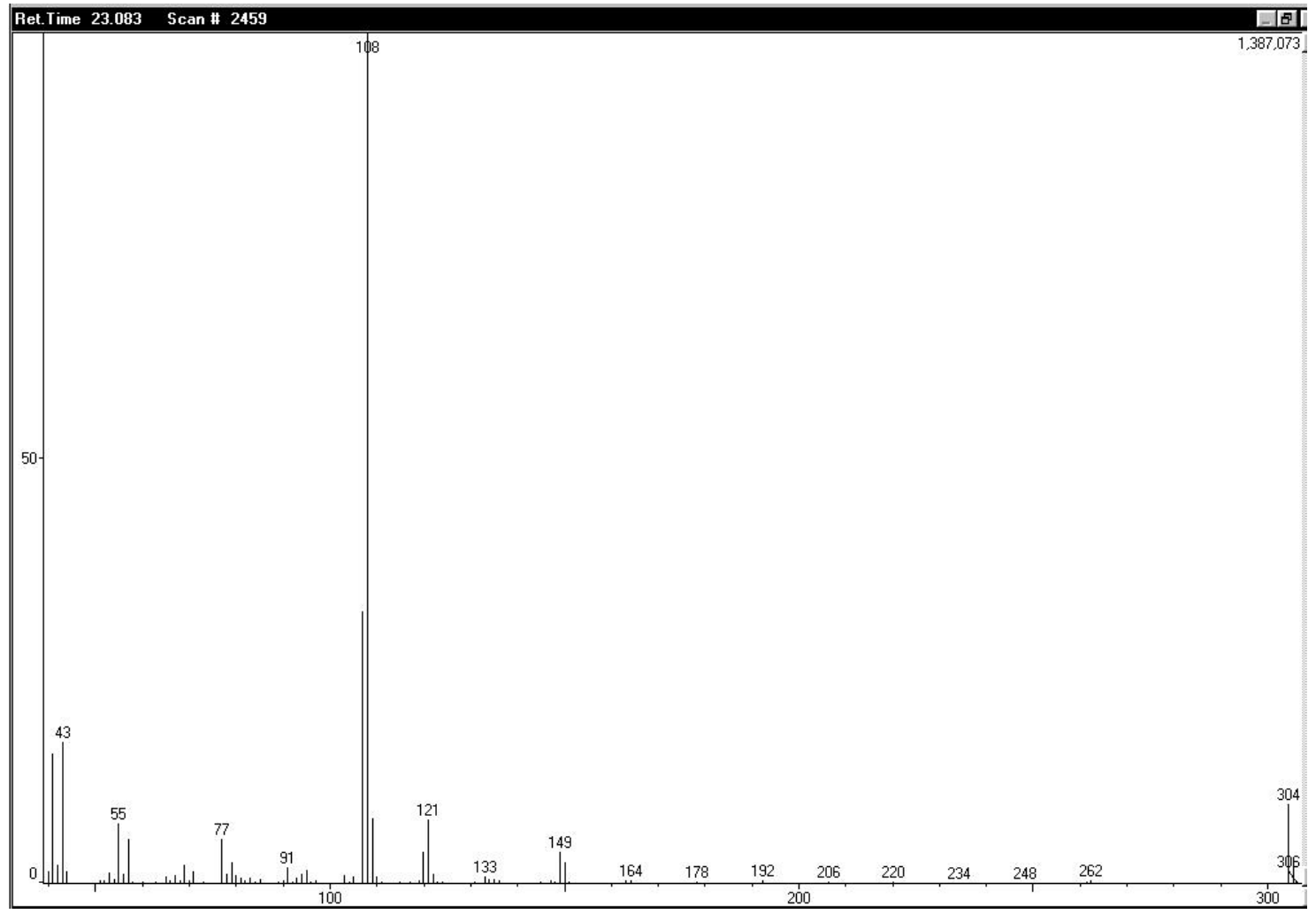

Figure 4. GC-EI-MS of the mass spectrum of 3-pentadecyl phenol or hydrocardanol (13). 


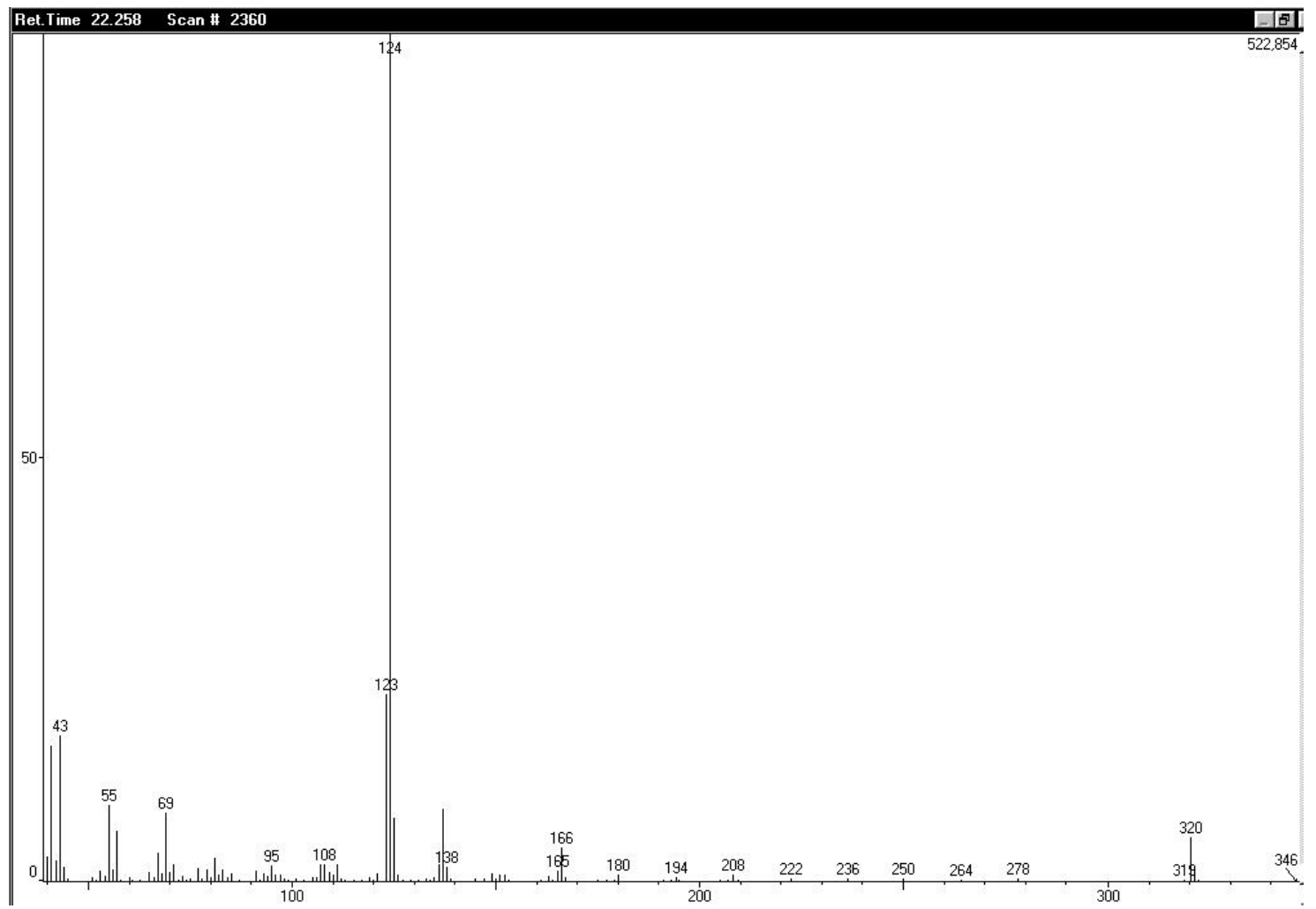

Figure 5. GC-EI-MS of the mass spectrum of 5-pentadecyl resorcinol or cardol (11).

Another sample of geopropolis harvested in Barra do Corda, exhibited an anti-tumoral effect on the solid Ehrlich tumor and on tumor-bearing mice lymphoid organs (Araújo et al., 2010). There are less reports about the chemical composition and biological activity of the Scaptotrigona genus than of the Melipona genus. Flavonol methyl ethers and methoxychalcones were detected in the geopropolis from Scaptotrigona aff. depillis harvested in the State of Rio Grande do Norte, northeastern Brazil, for which the resin source was Mimosa tenuiflora (Ferreira et al., 2017). Regional and seasonal differences were observed in the chemical compositions of geopropolis samples from Scaptotrigona spp., Scaptotrigona depillis and Scaptotrigona bipunctata, harvested monthly from two distinct Brazilian states, Maranhão and São Paulo. Diterpene acid derivatives were detected in the three geopropolis samples. However, the chemical profile obtained for the geopropolis from Scaptotrigona ssp, harvested in Maranhão State was different from that obtained for the geopropolis from the Scaptotrigona species, harvested in the state of São Paulo (Sawaya et al., 2009, 2007). The results obtained by Sawaya et al. (2009) indicated that the geopropolis from Scaptotrigona spp., harvested in Maranhão State, probably used Schinus terebenthifolius and conifers as the resin sources, while Hymenaea courbaril (Caesalpinioideae) was the resin source used for the geopropolis obtained from Scaptotrigona depillis and Scaptotrigona bipunctata, harvested in São Paulo state. On the other hand, the steroid ethisterone and cardanol were found in the geopropolis from Scaptotrigona aff. postica harvested in São Paulo city, which exhibited cytotoxic activity for all cells (Sanches, 2014).

The pollen spectrum of the geopropolis from S. postica harvested in Barra do Corda, exhibited 94 pollen types belonging to 35 plant families, the families Fabaceae and Rubiaceae exhibiting the highest pollen contents. The most frequent pollen types found were Borreria verticillata, Anadenanthera sp. and Mimosa caesalpiniifolia (Souza et al., 2015). Amongst the pollen types, 34 unique pollen types occurred in a given month of the year, which were characterized as seasonal indicators of flowering species, influenced by seasonal and interannual variations in climate (Souza et al., 2015). Much research has been carried out 
using cardanol, suggesting different types of applications for this compound and its derivatives (Barbosa et al., 2019; Mubofu \& Mgaya, 2018).

Cardanol and cardol are non-polar compounds typical of plants of the genus of the family Anacardiaceae, both in native and cultivated cultures. Anacardic acid, cardanol, cardol and methyl cardol, with different degrees of unsaturation (monoene-15:1, diene-15:2, and triene-15:3), were isolated from cashew (Anacardium occidentale), family Anacardiaceae (Morais et al., 2017; Fadeyi et al., 2015; Gómez-Caravaca et al., 2010). Thus, possibly a plant of the Anacardiaceae family, probably Anacardium occidentale and/or Mangifera indica, could be the resin source for this propolis.

Cardanols, known as phenolic lipids, due to their amphiphilic character derived from a hydrophilic hydroxyl group and a hydrophobic long chain hydrocarbon (Stasiuk \& Kozubek, 2010), were detected in fungi, bacteria and in propolis obtained from Apis mellifera (Boonsai et al., 2014; Teerasripreecha et al., 2012) and from stingless bees (Araújo et al., 2015; Sanches, 2014). The presence of cardanols in the propolis obtained from Teresina, Piauí State, northeastern Brazil, was attributed to the presence of several cashew trees (Anacardium occidentale) around the apiary (Silva et al., 2008). Cardanols were detected in Brazilian green propolis from São Paulo State, (Negri et al., 2003); in propolis from Oman, a country located on the southeastern coast of the Arabian Peninsula in Western Asia (Popova et al., 2013), and in propolis samples harvested in Thailand and in Indonesia (Teerasripreecha et al., 2012). The presence of these compounds in propolis from Thailand, Indonesia and Oman indicated that Mangifera indica (Anacardiaceae) was the resin source (Popova et al., 2013; Teerasripreecha et al., 2012).

Thirteen alkenylphenols and nine alkenylresorcinols were detected in propolis from North-Western Cameroon, along with triterpenoids (Kardar et al., 2014). In Thai Apis mellifera propolis from different locations triterpenes and three inseparable mixtures of phenolic lipids (cardols, cardanols and anacardic acids) were detected, indicating mango (Mangifera indica) as the resin source (Sanpa et al., 2017). Thai Apis mellifera propolis is a tropical propolis type, which exhibited considerable antibacterial activities (Sanpa et al., 2017). Beside this, large amounts of cardanols and cardols were detected in the geopropolis produced by Melipona fasciculata Smith from Palmeirândia, Maranhão State, northeastern Brazil (Araújo et al., 2015) and in the geopropolis from Scaptotrigona aff. Postica, harvested in São Paulo city (Sanches, 2014). Alkenylresorcinols were isolated from the Indonesian propolis from East Java, that used Macaranga tanarius L. and Mangifera indica L. as the resin sources (Trusheva et al., 2011). Three ent-kaurene diterpenoids were isolated from a sample collected by the native Brazilian bees Melipona quadrifasciata anthidioides. Kaurenoic acid, as well as the total extract, exhibited moderate antibacterial activity (Velikova et al., 2000).

Some studies have demonstrated interesting biological activities exhibited by non-polar extracts of geopropolis. The hexane fractions of the geopropolis from Melipona scutellaris, harvested in the Atlantic forest of Bahia State (Northeastern Brazil), exhibited considerable antibacterial activity against Streptococcus mutans, antitumoral activities against human cancer cell lines (Cunha et al., 2013a) and antinociceptive activity (Franchin et al., 2012). The hexane extract of the geopropolis from Melipona mondury, which possesses anacardic acid derivatives as constituents, exhibited antioxidant, antibacterial and antiproliferative activities (Santos et al., 2017a).

Phenolic lipids can be incorporated into erythrocytes and liposomal membranes due to their hydrophilic (water-loving, polar) and lipophilic (fat-loving) properties (Stasiuk \& Kozubek, 2010; Kruk et al., 2017) and can be used in pharmaceutical and fine chemical processes (Saladino et al., 2008; Behalo et al., 2016). Beside this, they also exhibited antioxidant (Andrade et al., 2011; Luís et al., 2016), antibacterial (Sibandze et al., 2016), antifeedant, cytotoxic, anticarcinogenic (Kruk et al., 2017), antiproliferative, antileishmanial, antigenotoxic (Parikka et al., 2006), antifungal (Popova et al., 2013) and anti-acetylcholinesterase activities (Oliveira et al., 2011). Cardanols are promising agents for the control of Aedes aegypti, the main dengue vector in Brazil, due to their larvicidal activity (Oliveira et al., 2011). 
The unsaturated cardanols 3-(4,7-heptadecadienyl) phenol (5), 3-(10-heptadecenyl) phenol (7) and 3-(8pentadecenyl) phenol (12) were found in large amounts in these non-polar propolis extracts from S. postica. According to Stasiuk \& Kozubek (2010), cardanols with long unsaturated carbon chains (cardanols C15:1 and C17:1) exhibit more potent activities than those with long saturated chains (cardanols C13:0 and C15:0). The antibacterial activities of these compounds, inhibiting bacterial, fungal, protozoan and parasitic growth, such as Staphylococcus aureus, Escherichia coli, Candida tropicalis, Candida albicans, Mycobacterium smegmatis and Mycobacterium aurum, depend on their interaction with proteins and/or their membrane-disturbing properties (Stasiuk \& Kozubek, 2010; Kruk et al., 2017; Sibandze et al., 2016). Cardanol from the Thai Apis mellifera propolis, exhibited considerale antibacterial activity (Sanpa et al., 2017), promoting changes in the morphology of Escherichia coli, especially in the cell membrane and cell division (Boonsai et al., 2014).

The saturated cardanols, 3-heptadecylphenol (9) and 3-pentadecylphenol or hydrocardanol (13) were also detected in large amounts in these non-polar extracts. Cardanols C13:0 and C15:0 exhibited the greatest inhibitory effects on the human colon cancer cells HCT-116 and HT-29, and both decreases and increases in the side chain lengths of the cardanol diminished the anticancer activities (Zhu et al., 2012). Cardanols effectively inhibited tyrosinase activities (Yu et al., 2016) and as effective antioxidants exhibited antimutagenic and antitumoral activity. However, despite their chemoprotective capacity, the cardanols exhibited a tendency to induce DNA damage (Schneider et al., 2016).

The cardanol and cardol found in the propolis samples from Thailand and Indonesia exhibited potent anticancer activity (Teerasripreecha et al., 2012). The cardol (C15:0) isolated from Anacardium occidentale was cytotoxic to the murine B16-F10 melanoma cells (Kubo et al., 2011). Cardols exhibited many physiological and pathological processes related to the immune system, such as cell signaling and gene regulation (Kozubek \& Tyman, 1999). Beside this, they can induce the expression of a pro-inflammatory cytokine and the tumor necrosis factor (TNF- $\alpha$ ) and suppress regulatory cytokines, including interleukin (IL-10) and the interferons, IFN- $\alpha$ and IFN- $\beta$ (Hung et al., 2013). The cytotoxic activity of cardols was demonstrated against the human colon, breast, lung, central nervous, ovarian, cervical and hepatocarcinoma cancer cell lines (Kruk et al., 2017; Zhu et al., 2012). However, anticancer activity was demonstrated against the breast cancer BT-474 cell line and attributed to an increase in the phosphorylation of the extracellular signal-regulated kinases (ERK), JNK and classical MAP kinases (p38 MAPK), which can lead to the obstruction of DNA synthesis (Buahorm et al., 2015). 5-Pentadecatrienylresorcinol, prevented the generation of superoxide radicals catalyzed by xanthine oxidase without the inhibition of uric acid formation (Masuoka et al., 2015). Ent-kaurane diterpenoids exhibit a broad spectrum of potential therapeutic effects including anticancer activity (Pham et al., 2016).

\section{Conclusions}

Propolis from S. postica, harvested in Barra do Corda, Brazil, is a natural source of bioactive compounds with promising biological activities. Large amounts of cardanols were found in the non-polar extracts obtained using hexane and chloroform, and the biological activity of cardanols and cardols has been demonstrated in many research projects. These compounds can be used for industrial applications in the food industry and in the pharmaceutical industry for the development of new drugs.

\section{Acknowledgements}

The authors are grateful to the FAPESP (Fundação de Amparo à Pesquisa do Estado de São Paulo) and CAPES (Coordenação de Aperfeiçoamento de Pessoal de Nível Superior) for their financial support and Wilson Melo generously provided the geopropolis samples. 


\section{References}

Andrade, T. J. A. S., Araújo, B. Q., Citó, A. M. G. L., Silva, J., Saffi, J., Richter, M. F., \& Ferraz, A. B. F. (2011). Antioxidant properties and chemical composition of technical Cashew Nut Shell Liquid (tCNSL). Food Chemistry, 126(3), 1044-1048. http://dx.doi.org/10.1016/j.foodchem.2010.11.122

Araújo, M. J. A. M., Búfalo, M. C., Conti, B. J., Fernandes Junior, A., Trusheva, B., Bankova, V., \& Sforcin, J. (2015). The chemical composition and pharmacological activities of geopropolis produced by Melipona fasciculata Smith in Northeast Brazil. Journal of Molecular Pathophysiology, 4(1), 12-20. http://dx.doi.org/10.5455/jmp.20150204115607

Araújo, M. J. A. M., Dutra, R. P., Costa, G. C., Reis, A. S., Assunção, A. K. M., Libério, S. A., Maciel, M. C. G., Silva, L. A. Guerra, R. N. M., Ribeiro, M. N. S., \& Nascimento, F. R. F. (2010). Efeito do tratamento com própolis de Scaptotrigona aff. postica sobre o desenvolvimento do tumor de Ehrlich em camundongos. Brazilian Journal of Pharmacognosy, 20(4), 580-587. http://dx.doi.org/10.1590/S0102-695X2010000400018

Bankova, V., Christov, R., Marcucci, M. C., \& Popov, S. (1998). Constituents of Brazilian geopropolis. Zeitschrift für Naturforschung, 53(5-6), 402-406. http://dx.doi.org/10.1515/znc-1998-5-616

Barbosa, L. R., Souza, D. S., Queiroz Junior, L. H. K., Cunha Neto, A., Lima, D. P., Beatriz, A., Romao, W., Castro, E. V. R., \& Lacerda Junior, V. (2019). Unequivocal structural assignments of three cardanol derivatives: An experimental and theoretical approach. Journal of Molecular Structure, 1175, 357-366. http://dx.doi.org/10.1016/j.molstruc.2018.07.112

Batista, M. C. A., Abreu, B. V. B., Dutra, R. P., Cunha, M. S., Amaral, F. M. M., Torres, L. M. B., \& Ribeiro, M. N. S. (2016). Chemical composition and antioxidant activity of geopropolis produced by Melipona fasciculata (Meliponinae) in flooded fields and cerrado areas of Maranhão State, northeastern Brazil. Acta Amazonica, 46(3), 315-322. http://dx.doi.org/10.1590/18094392201600034

Behalo, M. S., Bloise, E., Carbone, L., Sole, R. D., Lomonaco, D., Mazzetto, S. E., Mele, G., \& Mergola, L. (2016). Cardanolbased green nanovesicles with antioxidant and cytotoxic activities. Journal of Experimental Nanoscience, 11(16), $1274-1284$. http://dx.doi.org/10.1080/17458080.2016.1212407

Boonsai, P., Phuwapraisirisan, P., \& Chanchao, C. (2014). Antibacterial activity of a cardanol from Thai Apis mellifera propolis. International Journal of Medical Sciences, 11(4), 327-336. PMid:24578609. http://dx.doi.org/10.7150/ijms.7373

Buahorm, S., Puthong, S., Palaga, T., Lirdprapamongkol, K., Phuwapraisirisan, P., Svasti, J., \& Chanchao, C. (2015). Cardanol isolated from Thai Apis mellifera propolis induces cell cycle arrest and apoptosis of BT-474 breast cancer cells via p21 upregulation. Daru: Journal of Faculty of Pharmacy, Tehran University of Medical Sciences, 23(1), 55. PMid:26694491. http://dx.doi.org/10.1186/s40199-015-0138-1

Carneiro, M. J., López, B. G.-C., Lancellotti, M., Franchi, G. C., Nowill, A. E., \& Sawaya, A. C. H. F. (2016). Evaluation of the chemical composition and biological activity of extracts of Tetragonisca angustula propolis and Schinus terebinthifolius Raddi (Anacardiaceae). Journal of Apicultural Research, 55(4), 315-323. http://dx.doi.org/10.1080/00218839.2016.1243295

Coelho, G. R., Figueiredo, C. A., Negri, G., Fernandes-Silva, C. C., Villar, K. D. S., Badari, J. C., Oliveira, M. I. D., Barbosa, T. F., Taniwaki, N. N., Namiyama, G. M., \& Mendonca, R. Z. (2018). Antiviral activity of hydromethanolic extract of geopropolis from scaptotrigona postica against rubella virus. Journal of Food Research, 7(6), 91. http://dx.doi.org/10.5539/jfr.v7n6p91

Coelho, G. R., Mendonça, R. Z., Vilar, K. S., Figueiredo, C. A., Badari, J. C., Taniwaki, N., Namiyama, G., Oliveira, M. I., Curti, S. P., Evelyn Silva, P., \& Negri, G. (2015). Antiviral action of hydromethanolic extract of geopropolis from scaptotrigona postica against antiherpes simplex virus (HSV-1). Evidence-Based Complementary and Alternative Medicine, 2015, 296086. PMid:25861357. http://dx.doi.org/10.1155/2015/296086

Cunha, M. G., Franchin, M., Galvão, L. C. C., Bueno-Silva, B., Ikegaki, M., Alencar, S. M., \& Rosalen, P. L. (2013a). Apolar bioactive fraction of Melipona scutellaris Geopropolis on Streptococcus mutans biofilm. Evidence-Based Complementary and Alternative Medicine, 2013, 256287. PMid:23843868. http://dx.doi.org/10.1155/2013/256287

Cunha, M. G., Franchin, M., Galvão, L. C. C., Ruiz, A. L. T. G., Carvalho, J. E., Ikegaki, M., Alencar, S. M., Koo, H., \& Rosalen, P. L. (2013b). Antimicrobial and antiproliferative activities of stingless bee Melipona scutellaris geopropolis. BMC Complementary and Alternative Medicine, 13, 23. PMid:23356696. http://dx.doi.org/10.1186/1472-6882-13-23

Cunha, M. G., Rosalen, P. L., Franchin, M., De Alencar, S. M., Ikegaki, M., Ransom, T., \& Beutler, J. A. (2016). Antiproliferative constituents of geopropolis from the bee Melipona scutellaris. Planta Medica, 82(3), 190-194. PMid:26544117. http://dx.doi.org/10.1055/s-0035-1558142

Dutra, R. P., Abreu, B. V. B., Cunha, M. S., Batista, M. C. A., Torres, L. M. B., Nascimento, F. R. F., Ribeiro, M. N. S., \& Guerra, R. N. M. (2014). Phenolic acids, hydrolyzable tannins, and antioxidant activity of geopropolis from the stingless bee Melipona fasciculata Smith. Journal of Agricultural and Food Chemistry, 62(12), 2549-2557. PMid:24571707. http://dx.doi.org/10.1021/jf404875v

Dutra, R. P., Nogueira, A. M. C., Marques, R. R. O., Costa, M. C. P., \& Ribeiro, M. N. S. (2008). Pharmacognostic evaluation of geopropolis of Melipona fasciculata Smith from Baixada Maranhense, Brazil. Brazilian Journal of Pharmacognosy, 18, 557-562. http://dx.doi.org/10.1590/S0102-695X2008000400010

Fadeyi, O. E., Olatunji, G. A., \& Ogundele, V. A. (2015). Isolation and characterization of the chemical constituents of Anacardium occidentale cracked bark. Natural Products Chemistry \& Research, 3, 192. http://dx.doi.org/10.4172/23296836.1000192

Fernandes-Silva, C. C., Salatino, A., Salatino, M. L. F., Breyer, E. D. H., \& Negri, G. (2013). Chemical profiling of six samples of Brazilian propolis. Química Nova, 36(2), 237-240. http://dx.doi.org/10.1590/S0100-40422013000200006 
Ferreira, J. M., Fernandes-Silva, C. C., Salatino, A., Message, D., \& Negri, G. (2017). Antioxidant activity of a geopropolis from northeast Brazil: Chemical characterization and likely botanical origin. Evidence-Based Complementary and Alternative Medicine, 2017, 4024721. PMid:29234387. http://dx.doi.org/10.1155/2017/4024721

Franchin, M., Cunha, M. G., Denny, C., Napimoga, M. H., Cunha, T. M., Koo, H., Alencar, S. M., Ikegaki, M., \& Rosalen, P. L. (2012). Geopropolis from Melipona scutellaris decreases the mechanical inflammatory hypernociception by inhibiting the production of IL-1 beta and TNF-alpha. Journal of Ethnopharmacology, 143(2), 709-715. PMid:22885134. http://dx.doi.org/10.1016/j.jep.2012.07.040

Freitas, M. O., Ponte, F. A. F., Lima, M. A. S., \& Silveira, E. R. (2008). Flavonoids and triterpenes from the nest of the stingless bee Trigona spinipes. Journal of the Brazilian Chemical Society, 19(3), 532-535. http://dx.doi.org/10.1590/S010350532008000300022

Geerkens, C. H., Matejka, A. E., Carle, R., \& Schweiggert, R. M. (2015). Development and validation of an HPLC method for the determination of alk(en)ylresorcinols using rapid ultrasound-assisted extraction of mango peels and rye grains. Food Chemistry, 169, 261-269. PMid:25236225. http://dx.doi.org/10.1016/j.foodchem.2014.08.001

Gómez-Caravaca, A. M., Verardo, V., \& Caboni, M. F. (2010). Chromatographic techniques for the determination of alkylphenols, tocopherols and other minor polar compounds in raw and roasted cold pressed cashew nut oils. Journal of Chromatography. A, 1217(47), 7411-7417. PMid:20961547. http://dx.doi.org/10.1016/j.chroma.2010.09.054

Hernández-García, E., García, A., Garza-González, E., Avalos-Alanís, F. G., Rivas-Galindo, V. M., Rodríguez-Rodríguez, J., Alcantar-Rosales, V. M., Delgadillo-Puga, C., \& Del Rayo Camacho-Corona, M. (2019). Chemical composition of Acacia farnesiana (L) wild fruits and its activity against Mycobacterium tuberculosis and dysentery bacteria. Journal of Ethnopharmacology, 230, 74-80. PMid:30367988. http://dx.doi.org/10.1016/j.jep.2018.10.031

Huang, S., Zhang, C.-P., Wang, K., Li, G. Q., \& Hu, F. L. (2014). Recent advances in the chemical composition of propolis. Molecules, 19(12), 19610-19632. PMid:25432012. http://dx.doi.org/10.3390/molecules191219610

Hung, C. H., Yang, S. N., Wang, Y. F., Liao, W. T., Kuo, P. L., Tsai, E. M., Lee, C. L., Chao, Y. S., Yu, H. S., Huang, S. K., \& Suen, J. L. (2013). Environmental alkylphenols modulate cytokine expression in plasmacytoid dendritic cells. PLoS One, 8(9), e73534. PMid:24039973. http://dx.doi.org/10.1371/journal.pone.0073534

Irawan, C., Hanafi, F., Sulistiawaty, L., \& Sukiman, M. (2018). Volatile compound analysis using GC-MS, phytochemical screening and antioxidant activities of the Husk of "Julang-Jaling" (Archidendron bubalinum (Jack) I.C Nielsen) from Lampung, Indonesia. Pharmacognosy Journal, 10(1), 92-98. http://dx.doi.org/10.5530/pj.2018.1.17

Kardar, M. N., Zhang, T., Coxon, G. D., Watson, D. G., Fearnley, J., \& Seidel, V. (2014). Characterisation of triterpenes and new phenolic lipids in Cameroonian própolis. Phytochemistry, 106, 156-163. PMid:25104230. http://dx.doi.org/10.1016/j.phytochem.2014.07.016

Kozubek, A., \& Tyman, J. H. P. (1999). Resorcinolic Lipids, the natural non-isoprenoid phenolic amphiphiles and their biological activity. Chemical Reviews, 99(1), 1-26. PMid:11848979. http://dx.doi.org/10.1021/cr970464o

Kruk, J., Aboul-Enein, B., Bernstein, J., \& Marchlewicz, M. (2017). Dietary alkylresorcinols and cancer prevention: A systematic review. European Food Research and Technology, 243(10), 1693-1710. http://dx.doi.org/10.1007/s00217-017-2890-6

Kubo, I., Nitoda, T., Tocoli, F. E., \& Green, I. R. (2011). Multifunctional cytotoxic agents from Anacardium occidentale. Phytotherapy Research, 25(1), 38-45. PMid:20623613. http://dx.doi.org/10.1002/ptr.3109

Kusch, P., Deininger, S., Specht, S., Maniako, R., Haubrich, S., Pommerening, T., Lin, P. K., Hoerauf, A., \& Kaiser, A. (2011). In vitro and in vivo antimalarial activity assays of seeds from Balanites aegyptiaca: Compounds of the extract show growth inhibition and activity against plasmodial aminopeptidase. Journal of Parasitology Research, 2011, 368692. PMid:21687598. http://dx.doi.org/10.1155/2011/368692

Liberio, S. A., Pereira, A. L., Dutra, R. P., Reis, A. S., Araújo, M. J., Mattar, N. S., Silva, L. A., Ribeiro, M. N., Nascimento, F. R. Guerra, R. N., \& Monteiro-Neto, V. (2011). Antimicrobial activity against oral pathogens and immunomodulatory effects and toxicity of geopropolis produced by the stingless bee Melipona fasciculata Smith. BMC Complementary and Alternative Medicine, 11(1), 108. PMid:22053900. http://dx.doi.org/10.1186/1472-6882-11-108

Luís, Â., Domingues, F., \& Duarte, A. P. (2016). Biological properties of plant-derived alkylresorcinols: Mini-review. MiniReviews in Medicinal Chemistry, 16(11), 851-854. PMid:26864549. http://dx.doi.org/10.2174/1389557516666160211121437

Luque de Castro, M. D., \& García-Ayuso, L. E. (1998). Soxhlet extraction of solid materials: An outdated technique with a promising innovative future. Analytica Chimica Acta, 369(1-2), 1-10. http://dx.doi.org/10.1016/S0003-2670(98)00233-5

Masuoka, N., Nihei, K., Maeta, A., Yamagiwa, Y., \& Kubo, I. (2015). Inhibitory effects of cardols and related compounds on superoxide anion generation by xanthine oxidase. Food Chemistry, 166, 270-274. PMid:25053055.

http://dx.doi.org/10.1016/j.foodchem.2014.06.021

McNeil, M. J., Porter, R. B. R., Rainford, L., Dunbar, O., Francis, S., Laurieri, N., \& Delgoda, R. (2018). Chemical composition and biological activities of the essential oil from Cleome rutidosperma DC. Fitoterapia, 129, 191-197. PMid:29981873. http://dx.doi.org/10.1016/j.fitote.2018.07.006

Morais, S. M., Silva, K. A., Araujo, H., Vieira, I. G. P., Alves, D. R., Fontenelle, R. O. S., \& Silva, A. M. S. (2017). Anacardic acid constituents from cashew nut shell liquid: NMR characterization and the effect of unsaturation on its biological activities. Pharmaceuticals, 10(1), 31. PMid:28300791. http://dx.doi.org/10.3390/ph10010031

Mubofu, E. B., \& Mgaya, J. E. (2018). Chemical valorization of cashew nut shell waste. Topics in Current Chemistry, $376(2), 8$. PMid:29442189. http://dx.doi.org/10.1007/s41061-017-0177-9 
Negri, G., Salatino, M. L. F., \& Salatino, A. (2003). Unusual chemical composition of a sample of Brazilian propolis as assessed by analysis of a chloroform extract. Journal of Apicultural Research, 42(4), 53-56.

http://dx.doi.org/10.1080/00218839.2003.11101092

Oliveira, M. S., Morais, S. M., Magalhães, D. V., Batista, W. P., Vieira, I. G., Craveiro, A. A., Manezes, J. E., Carvalho, A. F., \& Lima, G. P. (2011). Antioxidant, larvicidal and antiacetylcholinesterase activities of cashew nut shell liquid constituents. Acta Tropica, 117(3), 165-170. PMid:20707981. http://dx.doi.org/10.1016/j.actatropica.2010.08.003

Oliveira, P. F., Souza Lima, I. M., Munari, C. C., Bastos, J. K., Da Silva Filho, A. A., \& Tavares, D. C. (2014). Comparative evaluation of antiproliferative effects of Brazilian green propolis, its main source Baccharis dracunculifolia, and their major constituents artepillin C and baccharin. Planta Medica, 80(6), 490-492. PMid:24687736. http://dx.doi.org/10.1055/s-00341368298

Parikka, K., Rowland, I. R., Welch, R. W., \& Wähälä, K. (2006). In vitro antioxidant activity and antigenotoxicity of 5-nalkylresorcinols. Journal of Agricultural and Food Chemistry, 54(5), 1646-1650. PMid:16506814. http://dx.doi.org/10.1021/jf052486e

Pasupuleti, V. R., Sammugam, L., Ramesh, N., \& Gan, S. H. (2017). Honey, propolis, and royal jelly: A comprehensive review of their biological actions and health benefits. Oxidative Medicine and Cellular Longevity, 2017, 1259510. PMid:28814983. http://dx.doi.org/10.1155/2017/1259510

Pedro, S. R. M. (2014). The stingless bee fauna in Brazil (Hymenoptera: apidae). Sociobiology, 61(4), 348-354. http://dx.doi.org/10.13102/sociobiology.v61i4.348-354

Pham, M. Q., Iscache, A. L., Pham, Q. L., \& Gairin, J. E. (2016). Cytotoxic, apoptotic, and sensitization properties of entkaurane-type diterpenoids from Croton tonkinensis Gagnep on human liver cancer HepG2 and Hep3b cell lines. Fundamental \& Clinical Pharmacology, 30(2), 137-146. PMid:26713517. http://dx.doi.org/10.1111/fcp.12176

Popova, M., Dimitrova, R., Al-Lawati, H. T., Tsvetkova, I., Najdenski, H., \& Bankova, V. (2013). Omani propolis: Chemical profiling, antibacterial activity and new propolis plant sources. Chemistry Central Journal, 7(1), 158. PMid:24053750. http://dx.doi.org/10.1186/1752-153X-7-158

Ribeiro-Junior, J. A., Franchin, M., Cavallini, M. E., Denny, C., Alencar, S. M., Ikegaki, M., \& Rosalen, P. L. (2015). Gastroprotective effect of geopropolis from Melipona scutellaris is dependent on production of nitric oxide and prostaglandin. Evidence-Based Complementary and Alternative Medicine, 2015, 459846. PMid:25949263. http://dx.doi.org/10.1155/2015/459846

Righi, A. A., Negri, G., \& Salatino, A. (2013). Comparative chemistry of propolis from eight brazilian localities. Evidence-Based Complementary and Alternative Medicine, 2013, 267878. PMid:23690840. http://dx.doi.org/10.1155/2013/267878

Ross, A. B., Åman, P., Andersson, R., \& Kamal-Eldin, A. (2004). Chromatographic analysis of alkylresorcinols and their metabolites. Journal of Chromatography A, 1054(1-2), 157-164. PMid:15553140. http://dx.doi.org/10.1016/j.chroma.2004.04.020

Saitta, M., Giuffrida, D., La Torre, G. L., Potortì, A. G., \& Dugo, G. (2009). Characterization of alkylphenols in pistachio (Pistacia vera L.) kernels. Food Chemistry, 117(3), 451-455. http://dx.doi.org/10.1016/j.foodchem.2009.04.043

Saladino, R., Gualandi, G., Farina, A., Crestini, C., Nencioni, L., \& Palamara, A. T. (2008). Advances and challenges in the synthesis of highly oxidised natural phenols with antiviral, antioxidant and cytotoxic activities. Current Medicinal Chemistry, 15(15), 1500-1519. PMid:18537626. http://dx.doi.org/10.2174/092986708784638889

Sanches, M. A. (2014). Effect of the propolis from Scaptotrigona aff. postica (Latreille, 1807) (Hymenoptera, Apidae, Meliponini) in some tumoral cells (Doctoral thesis). Universidade Federal de Viçosa, Viçosa.

Sanpa, S., Popova, M., Tunkasiri, T., Eitssayeam, S., Bankova, V., \& Chantawannakul, P. (2017). Chemical profiles and antimicrobial activities of Thai propolis collected from Apis mellifera. Warasan Khana Witthayasat Maha Witthayalai Chiang Mai, 44, 438-448.

Santos, C. M., Campos, J. F., Santos, H. F., Balestieri, J. B. P., Silva, D. B., Picoli Souza, K., Carollo, C. A., Estevinho, L. M., \& Santos, E. L. (2017a). Chemical composition and pharmacological effects of geopropolis produced by Melipona quadrifasciata anthidioides. Oxidative Medicine and Cellular Longevity, 2017, 8320804. PMid:29213354. http://dx.doi.org/10.1155/2017/8320804

Santos, H. F. D., Campos, J. F., Santos, C. M. D., Balestieri, J. B. P., Silva, D. B., Carollo, C. A., Picoli Souza, K., Estevinho, L. M., \& Santos, E. L. (2017b). Chemical profile and antioxidant, anti-inflammatory, antimutagenic and antimicrobial activities of geopropolis from the stingless bee Melipona orbignyi. International Journal of Molecular Sciences, 18(5), 953. PMid:28467350. http://dx.doi.org/10.3390/ijms18050953

Santos, T. L. A. D., Queiroz, R. F., Sawaya, A. C. H. F., Lopez, B. G.-C., Soares, M. B. P., Bezerra, D. P., Rodrigues, A. C. B. C., Paula, V. F. D., \& Waldschmidt, A. M. (2017c). Melipona mondury produces a geopropolis with antioxidant, antibacterial and antiproliferative activities. Anais da Academia Brasileira de Ciências, 89(3, Suppl.), 2247-2259. PMid:28746550. http://dx.doi.org/10.1590/0001-3765201720160725

Sawaya, A. C. H. F., Calado, J. C. P., Santos, L. C., Marcucci, M. C., Akatsu, I. P., Soares, A. E. E., Abdelnur, P. V., Cunha, I. B. S., \& Eberlin, M. N. (2009). Composition and antioxidant activity of propolis from three species of Scaptotrigona stingless bees. Journal of ApiProduct and ApiMedical Science, 1(2), 37-42. http://dx.doi.org/10.3896/IBRA.4.01.2.03

Sawaya, A. C. H. F., Cunha, I. B. S., Marcucci, M. C., Aidar, D. S., Silva, E. C. A., Carvalho, C. A. L., \& Eberlin, M. N. (2007) Electrospray ionization mass spectrometry fingerprinting of propolis of native Brazilian stingless bees. Apidologie, 38(1), 93-103. http://dx.doi.org/10.1051/apido:2006058 
Schneider, B. U., Meza, A., Beatriz, A., Pesarini, J. R., Carvalho, P. C., Mauro, M., Karaziack, C. B., Cunha-Laura, A. L., Monreal, A. C., Matuo, R., Lima, D. P., \& Oliveira, R. J. (2016). Cardanol: Toxicogenetic assessment and its effects when combined with cyclophosphamide. Genetics and Molecular Biology, 39(2), 279-289. PMid:27303909. http://dx.doi.org/10.1590/1678-4685-gmb-2015-0170

Sibandze, G., Stapleton, P., \& Gibbons, S. (2016). Isolation and characterisation of alkyl phenols from Ozoroa sphaerocarpa with antimicrobial activity. Planta Medica, 82(S01), S1-S381. http://dx.doi.org/10.1055/s-0036-1596405

Siddiquee, S., Al Azad, S., Abu Bakar, F., Naher, L., \& Kumar, S. V. (2015). Separation and identification of hydrocarbons and other volatile compounds from cultures of Aspergillus niger by GC-MS using two different capillary columns and solvents. Journal of Saudi Chemical Society, 19(3), 243-256. http://dx.doi.org/10.1016/j.jscs.2012.02.007

Silva, E. C. C., Muniz, M. P., Nunomura, R. C. S., Nunomura, S. M., \& Zilse, G. A. C. (2013). Phenolic Constituents and Antioxidant activity of geopropolis from two species of amazonian stingless bees. Química Nova, 36, 628-633. http://dx.doi.org/10.1590/S0100-40422013000500003

Silva, M. S. S., Lima, S. G., Oliveira, E. H., Lopes, J. A. D., Chaves, M. H., Reis, F. A. M., \& Citó, A. M. G. L. (2008). Anacardic acid derivatives from Brazilian propolis and their antibacterial activity. Eclética Química, 33(3), 53-58. http://dx.doi.org/10.1590/S0100-46702008000300008

Silva, T. M. S., Souza, S. A., Dias, T. L. M. F., Silva, T. M. G., Falcão, R. A., Alexandre-Moreira, M. S., Silva, E. M. S., \& Camara, C. A. (2014). Chemical composition, antinociceptive and free radical-scavenging activities of geopropolis from Melipona subnitida Ducke (Hymenoptera: Apidae: Meliponini). Sociobiology, 61(4), 560-565. http://dx.doi.org/10.13102/sociobiology.v61i4.560-565

Silva-Carvalho, R., Baltazar, F., Almeida-Aguiar, C., \& Almeida-Aguiar, C. (2015). Propolis: A complex natural product with a plethora of biological activities that can be explored for drug development. Evidence-Based Complementary and Alternative Medicine, 2015, 206439. PMid:26106433. http://dx.doi.org/10.1155/2015/206439

Souza, H. R., Corrêa, A. M. S., Cruz-Barros, M. A. V., \& Albuquerque, P. M. C. (2015). Espectro polínico da própolis de Scaptotrigona aff. postica (Hymenoptera, Apidae, Meliponini) em Barra do Corda, MA, Brasil. Acta Amazonica, 45(3), 307-316. http://dx.doi.org/10.1590/1809-4392201403663

Souza, S. A., Camara, C. A., Sarmento da Silva, E. M. S., \& Silva, T. M. S. (2013). Composition and antioxidant activity of geopropolis collected by Melipona subnitida (Jandaíra) bees. Evidence-Based Complementary and Alternative Medicine, 2013, 801383. PMid:23935683.

Souza, S. A., Silva, T. M. G., Silva, E. M. S., Camara, C. A., \& Silva, T. M. S. (2018). Characterization of phenolic compounds by UPLC-QTOF-MS/MS of geopropolis from the stingless bee Melipona subnitida (jandaíra). Phytochemical Analysis, 29(6), 549-558. PMid:29770982. http://dx.doi.org/10.1002/pca.2766

Stasiuk, M., \& Kozubek, A. (2010). Biological activity of phenolic lipids. Cellular and Molecular Life Sciences, 67(6), 841-860. PMid:20213924. http://dx.doi.org/10.1007/s00018-009-0193-1

Teerasripreecha, D., Phuwapraisirisan, P., Puthong, S., Kimura, K., Okuyama, M., Mori, H., Kimura, A., \& Chanchao, C. (2012) In vitro antiproliferative/cytotoxic activity on cancer cell lines of a cardanol and a cardol enriched from Thai Apis mellifera propolis. BMC Complementary and Alternative Medicine, 12(1), 518. PMid:22458642. http://dx.doi.org/10.1186/1472-6882-1227

Torres, A. R., Sandjo, L. P., Friedemann, M. T., Tomazzoli, M. M., Maraschin, M., Mello, C. F., \& Santos, A. R. S. (2018). Chemical characterization, antioxidant and antimicrobial activity of propolis obtained from Melipona quadrifasciata quadrifasciata and Tetragonisca angustula stingless bees. Brazilian Journal of Medical and Biological Research, 51(6), e7118. PMid:29791598. http://dx.doi.org/10.1590/1414-431x20187118

Trusheva, B., Popova, M., Koendhori, E. B., Tsvetkova, I., Naydenski, C., \& Bankova, V. (2011). Indonesian propolis: Chemical composition, biological activity and botanical origin. Natural Product Research, 25(6), 606-613. PMid:21409722. http://dx.doi.org/10.1080/14786419.2010.488235

Velikova, M., Bankova, V., Tsvetkova, I., Kujumgiev, A., \& Marcucci, M. C. (2000). Antibacterial ent-kaurene from Brazilian propolis of native stingless bees. Fitoterapia, 71(6), 693-696. PMid:11077178. http://dx.doi.org/10.1016/S0367-326X(00)00213-

Wheeler, T. F., Heim, J. R., Latorre, M. R., \& Janes, A. B. (1997). Mass Spectral characterization of p-nonylphenol isomers using high-resolution capillary GC-MS. Journal of Chromatographic Science, 35(1), 19-30. http://dx.doi.org/10.1093/chromsci/35.1.19

Xie, Y., Wang, J., Yang, F., \& Lei, C. (2011). Comparative analysis of essential oil components of two Cryptomeria species from China. Industrial Crops and Products, 34(1), 1226-1230. http://dx.doi.org/10.1016/j.indcrop.2011.04.016

Yu, X.-P., Su, W.-C., Wang, Q., Zhuang, J.-X., Tong, R.-Q., Chen, Q.-X., \& Chen, Q.-H. (2016). Inhibitory mechanism of cardanols on tyrosinase. Process Biochemistry, 51(12), 2230-2237. http://dx.doi.org/10.1016/j.procbio.2016.09.019

Zhao, L., Yu, M., Sun, M., Xue, X., Wang, T., Cao, W., \& Sun, L. (2017). Rapid determination of major compounds in the ethanol extract of geopropolis from Malaysian stingless bees, Heterotrigona itama, by UHPLC-Q-TOF/MS and NMR. Molecules, 22(11), 1935. PMid:29125569. http://dx.doi.org/10.3390/molecules22111935

Zhu, Y., Soroka, D. N., \& Sang, S. (2012). Synthesis and inhibitory activities against colon cancer cell growth and proteasome of alkylresorcinols. Journal of Agricultural and Food Chemistry, 60(35), 8624-8631. PMid:22897570.

http://dx.doi.org/10.1021/jf302872a 
Cardanols detected in non-polar propolis extracts from Scaptotrigona aff. postica (Hymenoptera, Apidae, Meliponini)

Negri, G. et al.

Funding: The authors are grateful to the Foundation for Research Support of the State of São Paulo - FAPESP (Fundação de Amparo à Pesquisa do Estado de São Paulo), processo

2013/07834-4. This study was financed in part by the

Coordenação de Aperfeiçoamento de Pessoal de Nível Superior - Brasil (CAPES) - Finance Code 001.

Received: Oct. 12, 2018; Accepted: Apr. 05, 2019 